\title{
ESTIMATION OF ARSENIC(III) IN ORGANIC ARSINES AND ITS COMPLEXES USING POTASSIUM BROMATE AND POTASSIUM IODATE AS OXIDANTS
}

\author{
ANU SHARMA ${ }^{a}$, GAURAV SHARMA ${ }^{a *}$, MU. NAUSHAD ${ }^{b *}$ AND DEEPAK PATHANIA ${ }^{a}$ \\ ${ }^{a}$ School of chemistry, Shoolini University, Solan-173212, Himachal Pradesh, India \\ ${ }^{b}$ Department of Chemistry, College of Science, Bld.\#5, King Saud University, Riyadh, Saudi Arabia
}

\begin{abstract}
Oxidimetric quantitative determination of arsenic(III) in organic arsines and their complexes with tin(IV) and mercury(II) has been attempted visually, potentiometrically and conductometrically. In each method, standard potassium bromate and potassium iodate oxidants were used in absolute alcohol medium. In these methods, known weight of organic arsines was dissolved in a mixture of absolute alcohol and concentrated hydrochloric acid. The resulting solution was titrated with standard potassium bromate/iodate solutions as oxidants using $\mathrm{CCl}_{4}$ as indicator in visual method. In case of conductometric and potentiometric titrations using potassium iodate/bromated, the results obtained were comparable to visual method. The percentage of arsenic for $1 / 10 \mathrm{~mol} \mathrm{~L}{ }^{-1} \mathrm{KIO}_{3}$ and $1 / 10 \mathrm{~mol}$ $\mathrm{L}^{-1} \mathrm{KBrO}_{3}$ were found to be $11.73 \%$ and $11.71 \%$, respectively. It led to the authenticity of the results obtained by visual method. $10 \mathrm{mg}$ to $20 \mathrm{mg}$ of the compound under test gave the results within the standard deviation error. The estimation of arsenic (III) was achieved within half an hour.
\end{abstract}

Keywords: Arsenic; Volumetric; Potentiometric; Conductometric.

\section{INTRODUCTION}

The group 15 elements such as phosphorus, arsenic, antimony and bismuth are deadly poisons, if their quantity is beyond a certain limit in medicine, water and air. The discharged water from the industries is unfit for drinking purpose. It contains large number of organic and inorganic pollutants. ${ }^{1-5}$ The major chunk of organic pollutants includes hazardous dyes such as methylene bule, malachite green or congo red etc. ${ }^{6-11}$ Whereas inorganic pollutants includes heavy metals and non metals i.e., lead, copper, nikel, cadmium, zinc, mercury and phosphorus, sulfur, selenium etc. ${ }^{12-15}$ The estimation of elements in water, medicines was important to know the exact quantity. Keeping this challenge in view, attempts have been made to devise cheap and less time consuming visual methods for the quantitative estimation of elements.

The estimation of non metals in inorganic and organic compounds has been of keen interest to scientists since 1865 . Generally, volumetric and gravimetric methods were previously used for the estimation of metals. The estimations have been reported in using non aqueous solvents like acetone, absolute alcohol or mineral acids. A brief survey of literature with respect to the estimation of various non metals in aqueous and non-aqueous medium has been reported Nitrogen in inorganic compounds has been estimated in glacial acetic acid using perchloric acid in dioxane as titrant. ${ }^{16}$ Nitrogen in nitrosodiphenylamine has been determined by treating the sample with naphthylamine in acetic acid and titrating the excess of naphthylamine with perchloric acid in acetic acid. ${ }^{17} \mathrm{~A}$ large number of aliphatic, aromatic and other bases were titrated with perchloric acid. ${ }^{18-20}$ The estimation of nitrogen in aromatic amines has been reported with chlorobenzene in acetic acid. ${ }^{21}$ The weak bases which cannot be determined visually or potentiometrically, either in acetic acid or in propionic acid, can be titrated in acetic anhydride with perchloric acid in acetic acid. ${ }^{22,23}$

In order to estimate sulphur, it has been found that mercapto group in thioglycolic acid, thiourea and thiosemicarbazide can be oxidized in the lead tetra-acetate to various oxidation states depending on the nature of the medium. In glacial acetic acid these compounds were oxidized to disulphides. The end point was detected potenteometrically or visually using quinalizarine in glacial acetic acid. ${ }^{24}$ Mendeleev has been directly titrated sulphuric acid with lead nitrate in the presence of alcohol using a few drops of potassium iodide as an indicator. ${ }^{25}$ Cassidy has reported the electrometric method for the precipitation of sulphate with lead nitrate in alcoholic medium.$^{26}$ The excess of lead was determined by titration with potassium chromate. The interference of iron, acetate ions, phosphate and aluminium has been reported during the process.

Konovalov has estimated the fluoride by titrating fluoride solution using ferrous chloride with murexide as an indicator. ${ }^{27-29}$ The estimation of chloride ion in chlorite ion was carried out by the addition of potassium iodide and acetic acid or sulphuric acid. The liberated iodine was titrated with sodium thiosulphate. The reaction in acetic acid was reported slow. ${ }^{30,31}$ Undoubtedly, one of the most satisfactory argentometrictitration method employed was the volhard titration. The results were found improved with the addition of nitrobenzene. ${ }^{32-34}$
Literature survey indicated that the estimation of arsenic in organic compounds was usually very tedious, difficult and lengthy. ${ }^{35,36}$ In a gravimetric method, the sample was fused in stainless steel bomb with decalin, and arsenous oxide so formed, is dissolved in sodium hydroxide. It has been determined gravimetrically as magnesium pyroarsenate. ${ }^{37}$ Paggi and Polverini has determined arsenic in some organic compounds by oxidizing the sample with a mixture of sulphuric acid and potassium persulphate. ${ }^{38}$ In this estimation, even a trace of water brings about absurd results. Das Gupta has estimated arsenic(III) in organic compounds by oxidizing the sample with hydrogen peroxide. ${ }^{39}$ The excess of potassium iodide was added and the liberated iodine is removed with standard sodium thiosulphate. After adding hydrochloric acid and acetic acid, the liberated iodine was titrated with sodium thiosulphate using starch as an indicator. In this method, the detection of end point is very difficult. Fargher oxidizes the sample with concentrated sulphuric acid and potassium permanganate ${ }^{40}$ In another method, an organic matter has been oxidized with a mixture of sulphuric and nitric acids. Arsenic was then determined by bromidebromate solution. However, nitrosyl group interferes. ${ }^{41}$ Theiodometric method suggested by Wintersteiner involved the reaction as. ${ }^{42}$

$$
\mathrm{H}_{3} \mathrm{AsO}_{4}+2 \mathrm{HI} \longrightarrow \mathrm{H}_{3} \mathrm{AsO}_{4}+\mathrm{I}_{2}+\mathrm{H}_{2} \mathrm{O}
$$

The liberated iodine was titrated against sodium thiosulphate solution. The quite interesting results were obtained at high acidic solution. Intolerable amount of bromine and iodine must be removed before the titration was carried out. Arsenic(III) has also been estimated in organic arsines using acetic acid, hydrochloric acid etc. ${ }^{43}$ The trace amount of triphenyl arsine in water has been determined by solid phase micro extraction and gas chromatography (with selective ion monitoring).The experimental results indicated that the recovery was found to be more than $95 \%$. The lowest detected concentrations 0.0005 $\mathrm{mg}$ per litre and the relative standard deviation of 7 times determinate was about $5.3 \%$. This method could satisfy the requirements of destruction of abandoned chemical weapons by Japan in China published in bioinformatics and biomedical engineering. ${ }^{44}$

Thus in view of above discussion, in the present investigation, a simple and new methods has been developed for the estimation of arsenic(III) in organic arsines and their complexes with tin(1V) and mercury(II).

\section{EXPERIMENTAL}

\subsection{Reagents}

The reagents used in this study were of analytical grade and used as received. Potassium iodate and potassium bromate were procured from $\mathrm{CDH}$, Pvt. Ltd. India. $\mathrm{CCl}_{4}$ was obtained from S.D. Fine Ltd. India. All the dilutions were made using double distilled water.

\subsection{Apparatus}

Semi micro burette of pyrex glass reading up to $0.01 \mathrm{~mL}$ was used 
for titration study. A digital conductometer (Systronics Pvt. Ltd., India, a digital potentiometer (Labtronics Pvt. Ltd. India), a digital electrical balance (Labtronics Pvt. Ltd., India) were used.

2.3. Procedure

2.3.1. Volumetric analysis

(i) Estimation of arsenic(III) using $1 / 10 \mathrm{~mol} \mathrm{~L}^{-1} \mathrm{KIO}_{3}$ oxidant

(a) Estimation of arsenic(III) in triphenyl arsines

In this method, a known weight of triphenyl arsine and other arsines were dissolved in $20-30 \mathrm{~mL}$ of absolute alcohol by warming in $100 \mathrm{~mL}$ beaker. The solution was cooled to room temperature $\left(20\right.$ to $\left.30^{\circ} \mathrm{C}\right)$. To this solution water was added drop wise until a slight milkiness appeared which is removed by adding a few drops of absolute alcohol. Then $10 \mathrm{~mL}$ of concentrated hydrochloric acid $\left(9 \mathrm{~mol} \mathrm{~L}^{-1}\right)$ were added to above mixture with continuous stirring. The milkiness did not appear again; otherwise add a few drops of absolute alcohol to make the solution clear. Now, $2-3 \mathrm{~mL}$ of $\mathrm{CCl}_{4}$ was added as an indicator. The solution was titrated with $1 / 10 \mathrm{~mol} \mathrm{~L}^{-1}$ potassium iodate till the end point reached. The end point was observed with the disappearance of violet coloured liquid to colourless liquid.

(b) Estimation of arsenic(III) in its complexes with tin(IV) and mercury(II)

The organic complexes with tin(1V) and mercury(II) containing arsenic(III) were partially soluble in absolute alcohol. Therefore, their complexes were dissolved in a mixture of $20 \mathrm{~mL}$ absolute alcohol and 2-3 $\mathrm{mL}$ of concentrated hydrochloric acid $\left(9 \mathrm{~mol} \mathrm{~L}^{-1}\right)$. The solution was titrated as per method described in part 2.3.1 $\mathrm{i}(\mathrm{a})$.

(ii) Estimation of arsenic (III) using $1 / 10 \mathrm{~mol} \mathrm{~L}^{-1} \mathrm{KBrO}_{3}$ oxidant

(a) Estimation of arsinic (III) in triphenylarsine

The solution of triphenyl arsine and other arsines were prepared as per the method discussed in i(a). In this case, about $9 \mathrm{~mol} \mathrm{~L}^{-1}$ concentrated hydrochloric acid was added with constant stirring. The solutions were titrated with $1 / 10$ mol L${ }^{-1} \mathrm{KBrO}_{3}$ using $\mathrm{CCl}_{4}$ as indicator. The end point was the disappearance of orange yellow coloured $\mathrm{CCl}_{4}$ liquid to colourless liquid. (II)

(b) Estimation of arsenic (III) in its complexes with tin (IV) and mercury

The solutions of complexes were prepared as per the method discussed in $2.3 .1 \mathrm{i}(\mathrm{b})$. The solutions were titrated with $1 / 10 \mathrm{~mol} \mathrm{~L}^{-1} \mathrm{KBrO}_{3}$ using $\mathrm{CCl}_{4}$ as indicator. The disappearance of orange yellow coloured $\mathrm{CCl}_{4}$ liquid to colourless liquid was the end point.

\subsubsection{Conductometric method}

(a) Estimation of arsenic (III) in triphenylarsine using 1/10 $\mathrm{mol} \mathrm{L}^{-1}$ $\mathrm{KIO}_{3}$ as oxidant

The solution of triphenylarsine was prepared by the same method as shown in 2.3.1 $\mathrm{i}$ (a) but no $\mathrm{CCl}_{4}$ was added as indicator. The solution was titrated with $1 / 10 \mathrm{~mol} \mathrm{~L}^{-1} \mathrm{KIO}_{3}$ and conductivity of solution for each addition of oxidant was noted. The volume of $\mathrm{KIO}_{3}$, after which the conductivity remained constant, indicated the end point.

(b) Estimation of arsenic (III) in triphenylarsine using $1 / 10 \mathrm{~mol} \mathrm{~L}^{-1}$ $\mathrm{KBrO}_{3}$ as oxidant

The solution of triphenylarsine was prepared by the same method as discussed in 2.3.1 i(a). The conductivity for each addition of oxidant was noted till the end point. The volume, after which the conduction remained constant, indicated the end point.

\subsubsection{Potentiometric method}

(a) Estimation of arsenic (III) in triphenylarsine using $1 / 10 \mathrm{~mol} \mathrm{~L}^{-1} \mathrm{KIO}_{3}$.

The solution of triphenylarsine was prepared by the same method as discussed in 2.3.1 i(a). The potential of each addition of oxidant was noted. The volume of $\mathrm{KIO}_{3}$, after which the potential remained constant, indicated the end point.

(b) Estimation of arsenic (III) in triphenylarsine using $1 / 10 \mathrm{~mol} \mathrm{~L}^{-1} \mathrm{KBrO}_{3}$ as oxidant

The solution of triphenylarsine was prepared by the same method as shown 2.3.1 $\mathrm{i}$ (a) but no $\mathrm{CCl}_{4}$ was added as an indicator. The solution was titrated with $1 / 10 \mathrm{~mol} \mathrm{~L}^{-1} \mathrm{KBrO}_{3}$ as shown in $2.3 .1 \mathrm{i}(\mathrm{b})$ and potential for each addition was noted. The volume of $\mathrm{KBrO}_{3}$, after which the potential remained constant, indicated the end point. This method involves the measurement of potential changes during the titration of unknown solution. In this method, two electrodes were used, one of which acts as indicator electrode while other acts as the reference electrode (calomel electrode).The indicator electrode showed the concentration of the ions to be titrated. It was added into the solution under estimation. The reference solution was connected to the solution under study with the help of salt bridge.

The oxidant was taken in a semi-micro burette while the reductant was taken in a beaker. When an oxidant was added to the reductant solution, a change of electrode potential took place. Then a graph was obtained between the volume of the oxidant added and the resulting electromotive force of the redox system. As a result, a curve was obtained, called oxidation-reduction curve. The ratios of the concentration of the oxidised and reduced substances give the determining factor. The value of the redox potential depends upon the nature of the system and concentration of the oxidised and reduced species. It can be calculated with the help of the following equation as:

$$
E=E^{0}+\frac{\mathbf{0 . 0 5 9 1}}{\mathbf{n}} \log \frac{\{\mathrm{Ox}\}}{\{\text { Red }\}}
$$

Where $\mathrm{E}=$ Required e.m.f. (Electro motive forces)

$\mathrm{E}^{0}=$ Standard redox potential of the system under study

$\mathrm{n}=$ Number of electrons involved in the redox reaction

$[\mathrm{ox}]=$ Concentration of oxidised form of the ions

$[\mathrm{Red}]=$ Concentration of reduced form of the ions

In case of the reaction:

Oxidised form + ne $\rightarrow$ reduced form,

The potential, E acquired by the indictor electrode was obtained from the equation (I) at $298 \mathrm{~K}$. The potential $\mathrm{E}$ of the indicator electrode was thus controlled by the concentration of the ions in the solution. During the redox reaction, the potential changes more rapidly near the end point. Thus, the titration of arsenic(III) (reductant) with potassium iodate/bromate (oxidant) can be carried out potentiometrically at $298 \mathrm{~K}$.

\section{RESULTS AND DISCUSSION}

\section{Visual method}

Arsenic atom in triphenyl arsine, $\left(\mathrm{C}_{6} \mathrm{H}_{5}\right)_{3} \mathrm{As}$ and its complexes have a lone pair of electrons. So, it acts as a reducing agent. Due to the -I effect of phenyl groups, the lone pair of electrons on arsenic atom were available to small extent. So, it also acts a lewis base. The behaviour of organic arsines due to these properties shows that these compounds quantitatively oxidised to arsenic(V) by oxidants like potassium iodate and potassium bromate in presence of concentrated $\mathrm{HCI}\left(9 \mathrm{~mol} \mathrm{~L}^{-1}\right)$ which helps to dissolve organic arsine complexes with metals such as tin(IV) and $\mathrm{Hg}$ (II).

\section{Estimation of arsenic (III) using $1 / 10 \mathrm{~mol} \mathrm{~L}^{-1} \mathrm{KIO}$ oxidant}

Table 1 shows the results of estimation of arsenic(III) using $1 / 10 \mathrm{~mol} \mathrm{~L}^{-1}$ $\mathrm{KIO}_{3}$ as oxidant. The results obtained were upto $99 \%$ probability truth of 24.53 \pm 0.11 .

Thus the method proposed for the estimation is simple and satisfactory than the other methods known. The standard redox potential of $\mathrm{IO}_{3}^{-} / \mathrm{I}^{-}$couple $(1.85 \mathrm{~V})$ was observed higher than that of oxygen/water couple $(1.23 \mathrm{~V})$, yet its aqueous solution if carefully prepared was quite stable.
$\mathrm{O}_{2+} 4 \mathrm{H}^{+}+4 \mathrm{e}^{-} \longrightarrow 2 \mathrm{H}_{2} \mathrm{O}$
$\mathrm{E}^{0}=1.23 \mathrm{~V}$
$\mathrm{IO}_{3}^{-}+6 \mathrm{H}^{+}+6 \mathrm{e} \longrightarrow \mathrm{I}^{-2}+3 \mathrm{H}_{2} \mathrm{O}$
$\mathrm{E}^{0}=1.85 \mathrm{~V}$

In acidic medium, potassium iodate acts as an oxidant according to the following equation.

$$
\mathrm{IO}_{3}^{-}+6 \mathrm{H}^{+}+4 \mathrm{e}^{-} \longrightarrow \mathrm{I}^{+}+3 \mathrm{H}_{2} \mathrm{O}
$$

The reaction of potassium iodate with aqueous ethyl alcohol (used to dissolve organic arsines and their complexes) is given below in presence of $\mathrm{CCl}_{4}$ (as indicator). During titration, the free iodine was available, which gets adsorbed on the indicator such as carbon tetrachloride, which resulted in the light violet color in $\mathrm{CCl}_{4}$. The disappearance of light violet colour in $\mathrm{CCl}_{4}$ was the ends point due to the formation of colourless $\mathrm{I}^{+} \mathrm{Cl}^{-}$. 


$$
\begin{aligned}
& \mathrm{IO}_{3+}^{-} 5 \mathrm{I}^{-}+6 \mathrm{H}^{+} \longrightarrow 3 \mathrm{I}_{2}+3 \mathrm{H}_{2} \mathrm{O} \\
& 2 \mathrm{IO}_{3}^{-}+2 \mathrm{C}_{2} \mathrm{H}_{5} \mathrm{OH}+\mathrm{CCI}_{4} \longrightarrow 2 \mathrm{C}_{2} \mathrm{H}_{5} \mathrm{O}^{-}+\left(\mathrm{I}_{2}+\mathrm{CCI}_{4}\right)+\mathrm{H}_{2} \mathrm{O}+5 \mathrm{O} \\
& \text { (Oxidant) (Solvent) (Indicator) (Light violet colour) } \\
& \mathrm{I}^{+}+\mathrm{Cl} \longrightarrow-\mathrm{ICl}
\end{aligned}
$$

The organic arsines and their complexes were either soluble in hot absolute alcohol or a mixture of absolute alcohol or concentrated hydrochloric acid Arsenic(III) present in these compounds was not oxidized to arsenic (V) in absolute alcohol. The addition of water till milkiness appeared and the removal of milkiness by the addition of minimum quantity of alcohol resulted in the quantitative estimation of As (III) in organic arsines to As(V) compounds. Triphenyl arsine exists in the absolute alcohol according to the following equilibrium as:

$$
\mathrm{C}_{2} \mathrm{H}_{5} \mathrm{OH}+\left(\mathrm{C}_{6} \mathrm{H}_{5}\right)_{3} \mathrm{As} \longrightarrow\left(\mathrm{C}_{6} \mathrm{H}_{5}\right)_{3} \mathrm{As} \mathrm{HOC}_{2} \mathrm{H}_{5} \longrightarrow\left(\mathrm{C}_{6} \mathrm{H}_{5}\right) \mathrm{As} \mathrm{H}^{+}+\mathrm{C}_{2} \mathrm{H}_{5} \mathrm{O}^{-}
$$

When water was added drop wise to the reaction mixture, the organic species separate out because the water is more basic than triphenly arsine. This reaction has been presented in the equation (7) as follows:

$$
\mathrm{C}_{6} \mathrm{H}_{5} \mathrm{As} \mathrm{H}^{+}+\mathrm{H}_{2} \mathrm{O} \longrightarrow\left(\mathrm{C}_{6} \mathrm{H}_{5}\right)_{3} \mathrm{As}+\mathrm{H}_{3} \mathrm{O}^{+}
$$

The oxidation of triphenyl arsine to triphenyl arsine oxide in presence of $\mathrm{CCl}_{4}$ and concentrated hydrochloric acid $\left(9 \mathrm{~mol} \mathrm{~L}^{-1}\right)$ by potassium iodate takes place, according to redox reaction as shown in equation(8). The disappearance of violet pink colour in tetrachloride layer was the end point of the reaction.

$$
\left(\mathrm{C}_{6} \mathrm{H}_{53} \mathrm{As}+\mathrm{O} \longrightarrow\left(\mathrm{C}_{6} \mathrm{H}_{5}\right)_{3} \mathrm{As}=\mathrm{O}\right.
$$

Estimation of arsenic(III) using 1/10 $\mathrm{mol} \mathrm{L}^{-1} \mathrm{KBrO}_{3}$ oxidant

Like potassium iodate, potassium bromate also acts as a powerful oxidant. Its standard redox potential $(1.52 \mathrm{~V})$ was higher as compared to water $(1.23 \mathrm{~V})$. It was used as an oxidant and its aqueous solution if carefully prepared, was quite stable.

$$
\begin{aligned}
& \mathrm{O}_{2}+4 \mathrm{H}^{+}+4 \mathrm{e}^{-} \longrightarrow 2 \mathrm{H}_{2} \mathrm{O} ; \mathrm{E}^{\mathrm{o}}=1.23 \mathrm{~V} \\
& \mathrm{BrO}_{3}^{-}+6 \mathrm{H}^{+}+6 \mathrm{e} \longrightarrow \mathrm{Br}^{-}+3 \mathrm{H}_{2} \mathrm{O}
\end{aligned}
$$

\begin{tabular}{|c|c|c|c|c|c|}
\hline \multicolumn{3}{|c|}{$1 / 10 \mathrm{~mol} \mathrm{~L}^{-1} \mathrm{KI} \mathrm{O}_{3}$} & \multicolumn{3}{|c|}{$1 / 10 \mathrm{~mol} \mathrm{~L}^{-1} \mathrm{KBrO}_{3}$} \\
\hline $\begin{array}{l}\text { Wt. of TPA taken } \\
(\mathrm{mg})\end{array}$ & $\begin{array}{l}\text { Wt. of TPA found } \\
\qquad(\mathrm{mg})\end{array}$ & $\begin{array}{l}\text { Percentage of arsenic } \\
\text { found }\end{array}$ & $\begin{array}{l}\text { Wt. of TPA taken } \\
(\mathrm{mg})\end{array}$ & $\begin{array}{l}\text { Wt. of TPA found } \\
\qquad(\mathrm{mg})\end{array}$ & $\begin{array}{l}\text { Percentage of arsenic } \\
\text { found }\end{array}$ \\
\hline 11.32 & 11.36 & 24.60 & 13.36 & 13.28 & 24.36 \\
\hline 9.98 & 10.02 & 24.60 & 14.10 & 14.02 & 24.37 \\
\hline 14.16 & 14.10 & 24.41 & 10.98 & 11.00 & 24.55 \\
\hline 15.02 & 14.98 & 24.44 & 9.78 & 9.86 & 24.71 \\
\hline 12.34 & 12.30 & 24.43 & 13.02 & 13.00 & 24.47 \\
\hline 11.76 & 11.86 & 24.72 & 11.78 & 11.70 & 24.34 \\
\hline 10.02 & 10.06 & 24.67 & 12.06 & 12.02 & 24.43 \\
\hline 11.12 & 11.16 & 24.60 & 10.10 & 10.16 & 24.66 \\
\hline 13.32 & 13.28 & 24.44 & 13.70 & 13.78 & 24.65 \\
\hline \multirow[t]{2}{*}{12.12} & 12.08 & 24.43 & 11.92 & 11.88 & 24.43 \\
\hline & & $\begin{array}{l}\text { Mean value } \\
=245.28 / 10 \\
=24.53\end{array}$ & & & $\begin{array}{l}\text { Mean value } \\
=244.97 / 10 \\
=24.50\end{array}$ \\
\hline \multicolumn{3}{|c|}{ Mean percentage of arsenic $=24.53$} & \multicolumn{3}{|c|}{ Mean percentage of arsenic $=24.50$} \\
\hline \multicolumn{3}{|c|}{ Required value $=24.51$} & \multicolumn{3}{|c|}{ Required value $=24.51$} \\
\hline \multicolumn{3}{|c|}{ Standard deviation $=0.11$} & \multicolumn{3}{|c|}{ Standard deviation $=0.13$} \\
\hline \multicolumn{3}{|c|}{$\begin{array}{l}\text { Results up to } 99 \% \text { probability } \\
\text { truth }=24.53 \pm 0.11\end{array}$} & \multicolumn{3}{|c|}{$\begin{array}{l}\text { Results up to } 99 \% \text { probability } \\
\text { truth }=24.50 \pm 0.13\end{array}$} \\
\hline
\end{tabular}

In acidic medium, potassium bromate acts as an oxidant according to the following equation (11) as:

$$
\mathrm{BrO}_{3}^{-}+6 \mathrm{H}^{+}+4 \mathrm{e}^{-} \longrightarrow \mathrm{Br}^{+}+3 \mathrm{H}_{2} \mathrm{O}
$$

Table1.Visual volumetric titration of triphenylarsine (TPA) with $1 / 10 \mathrm{~mol} \mathrm{~L}^{-1} \mathrm{KIO}_{3}$ and $1 / 10 \mathrm{~mol} \mathrm{~L}^{-1} \mathrm{KBrO}_{3}$

During titration, the free bromine was available which gets adsorbed on the indicator carbon tetrachloride. The disappearance of light yellow colour in $\mathrm{CCI}_{4}$ was the end point of the titration due to the formation of colourless $\mathrm{Br}^{+} \mathrm{Cl}^{-}$. The results of estimation of arsenic(III) using $1 / 10 \mathrm{~mol} \mathrm{~L}^{-1} \mathrm{KBrO}_{3}$ as oxidant were shown in Table 1. The analysis of organic compound (10-20 mg), with standard deviation of 0.13 has been obtained for arsenic.

The estimation of a few organic arsines such as 1,2- ethylene bis(diphenyl arsine) and 1,4 butylene bis(diphenyl arsine) with potassium iodate and potassium bromate oxidants were shown in Table 2 and 3. 
Table 2.Visual volumetric titration of 1,2 ethylene bis(diphenyl arsine) (EBDP) with $1 / 10 \mathrm{~mol} \mathrm{~L}^{-1} \mathrm{KI} \mathrm{O}_{3}$ and $1 / 10 \mathrm{~mol} \mathrm{~L}^{-1} \mathrm{KBrO}_{3}$

\begin{tabular}{|c|c|c|c|c|c|}
\hline \multicolumn{3}{|c|}{$1 / 10 \mathrm{~mol} \mathrm{~L}^{-1} \mathrm{KIO}_{3}$} & \multicolumn{3}{|c|}{$1 / 10 \mathrm{~mol} \mathrm{~L}^{-1} \mathrm{KBrO}_{3}$} \\
\hline $\begin{array}{l}\text { Wt. of EBDP taken } \\
(\mathrm{mg})\end{array}$ & $\begin{array}{l}\text { Wt. of EBDP found } \\
(\mathrm{mg})\end{array}$ & $\begin{array}{l}\text { Percentage of arsenic } \\
\text { found }\end{array}$ & $\begin{array}{l}\text { Wt. of EBDP taken } \\
(\mathrm{mg})\end{array}$ & $\begin{array}{l}\text { Wt. of EBDP found } \\
(\mathrm{mg})\end{array}$ & $\begin{array}{c}\text { Percentage of arsenic } \\
\text { found }\end{array}$ \\
\hline 12.66 & 12.58 & 30.66 & 13.76 & 13.82 & 30.99 \\
\hline 11.10 & 11.12 & 30.92 & 12.14 & 12.06 & 30.66 \\
\hline 9.98 & 10.06 & 31.11 & 9.94 & 9.98 & 30.98 \\
\hline 15.12 & 15.02 & 30.66 & 14.52 & 14.48 & 30.77 \\
\hline 11.14 & 11.08 & 30.69 & 12.88 & 12.98 & 31.01 \\
\hline 12.32 & 12.36 & 30.96 & 11.38 & 11.42 & 30.97 \\
\hline 14.56 & 14.48 & 30.69 & 17.60 & 17.56 & 30.79 \\
\hline 10.98 & 11.02 & 30.97 & 11.86 & 11.92 & 31.02 \\
\hline 13.32 & 13.36 & 30.95 & 12.02 & 12.06 & 30.96 \\
\hline \multirow[t]{2}{*}{10.28} & 10.32 & 30.98 & 13.38 & 13.46 & 31.04 \\
\hline & & $\begin{array}{c}\text { Mean value } \\
=307.59 / 10 \\
=30.76\end{array}$ & & & $\begin{array}{c}\text { Mean value } \\
=309.19 / 10 \\
=30.92\end{array}$ \\
\hline \multicolumn{3}{|c|}{ Mean percentage of arsenic $=30.76$} & \multicolumn{3}{|c|}{ Mean percentage of arsenic $=30.92$} \\
\hline \multicolumn{3}{|c|}{ Required value $=30.86$} & \multicolumn{3}{|c|}{ Required value $=30.86$} \\
\hline \multicolumn{3}{|c|}{ Standard deviation $=0.16$} & \multicolumn{3}{|c|}{ Standard deviation $=0.14$} \\
\hline \multicolumn{3}{|c|}{$\begin{array}{l}\text { Results up to } 99 \% \text { probability } \\
\text { truth }=30.76 \pm 0.16\end{array}$} & \multicolumn{3}{|c|}{$\begin{array}{l}\text { Results up to } 99 \% \text { probability } \\
\text { truth }=30.92 \pm 0.14\end{array}$} \\
\hline
\end{tabular}

Table 3.Visual volumetric titration of 1,4 Butylene bis(diphenyl arsine) (BBDP) with 1/10 $\mathrm{mol} \mathrm{L}^{-1} \mathrm{KI} \mathrm{O}_{3}$ and $1 / 10 \mathrm{~mol} \mathrm{~L}^{-1} \mathrm{KBrO}_{3}$

\begin{tabular}{|c|c|c|c|c|c|}
\hline \multicolumn{3}{|c|}{$1 / 10 \mathrm{~mol} \mathrm{~L}^{-1} \mathrm{KI} \mathrm{O}_{3}$} & \multicolumn{3}{|c|}{$1 / 10 \mathrm{~mol} \mathrm{~L}^{-1} \mathrm{KBrO}_{3}$} \\
\hline $\begin{array}{l}\text { Wt. of BBDP taken } \\
(\mathrm{mg})\end{array}$ & $\begin{array}{l}\text { Wt. of BBDP found } \\
(\mathrm{mg})\end{array}$ & $\begin{array}{l}\text { Percentage of arsenic } \\
\text { found }\end{array}$ & $\begin{array}{l}\text { Wt. of BBDP taken } \\
(\mathrm{mg})\end{array}$ & $\begin{array}{l}\text { Wt. of BBDP found } \\
(\mathrm{mg})\end{array}$ & $\begin{array}{l}\text { Percentage of arsenic } \\
\text { found }\end{array}$ \\
\hline 11.58 & 11.52 & 29.03 & 14.44 & 14.48 & 29.26 \\
\hline 10.22 & 10.26 & 29.29 & 13.36 & 13.32 & 29.09 \\
\hline 11.92 & 11.86 & 29.03 & 12.90 & 12.86 & 29.09 \\
\hline 10.76 & 10.82 & 29.34 & 11.78 & 11.82 & 29.08 \\
\hline 9.98 & 10.02 & 29.30 & 13.36 & 13.42 & 29.31 \\
\hline 13.78 & 13.82 & 29.26 & 11.88 & 11.84 & 29.08 \\
\hline 12.22 & 12.18 & 29.09 & 12.14 & 12.18 & 29.28 \\
\hline 11.88 & 11.92 & 29.28 & 10.86 & 10.92 & 29.34 \\
\hline 13.32 & 13.28 & 29.09 & 13.70 & 13.64 & 29.05 \\
\hline \multirow[t]{2}{*}{11.22} & 11.18 & 29.34 & 11.80 & 11.86 & 29.33 \\
\hline & & $\begin{array}{l}\text { Mean value } \\
=292.05 / 10 \\
=29.20\end{array}$ & & & $\begin{array}{l}\text { Mean value } \\
=291.19 / 10 \\
=29.19\end{array}$ \\
\hline \multicolumn{3}{|c|}{ Mean percentage of arsenic $=29.20$} & \multicolumn{3}{|c|}{ Mean percentage of arsenic $=29.19$} \\
\hline \multicolumn{3}{|c|}{ Required value $=29.18$} & \multicolumn{3}{|c|}{ Required value $=29.18$} \\
\hline \multicolumn{3}{|c|}{ Standard deviation $=0.13$} & \multicolumn{3}{|c|}{ Standard deviation $=29.19 \pm 0.12$} \\
\hline \multicolumn{3}{|c|}{$\begin{array}{l}\text { Results up to } 99 \% \text { probability } \\
\text { truth }=29.20 \pm 0.13\end{array}$} & \multicolumn{3}{|c|}{$\begin{array}{l}\text { Results up to } 99 \% \text { probability } \\
\text { truth }=29.19 \pm 0.12\end{array}$} \\
\hline
\end{tabular}

Table 2 inferred that the obtained results were of $99 \%$ probability truth with errors of 0.16 and 0.14 , respectively with potassium iodate and potassium bromate. Table 3 inferred that the results obtained for 1,4-butylene bis(diphenyl arsine) were of $99 \%$ probability truth with error of 0.13 and 0.12 with potassium iodate and potassium bromated, respectively.

The estimation of a complex of organic arsine with tin(IV) and $\mathrm{Hg}(\mathrm{II})$ using potassium iodate and potassium bromate oxidants were shown in Tables 4 and 5 . 
Table 4.Visual volumetric titration of Dibutyl tin(IV) bis(o-carboxyphenyl di- p-tolyl arsine) DBTC with 1/10 $\mathrm{mol} \mathrm{L}^{-1} \mathrm{KI} \mathrm{O}_{3}$ and $1 / 10 \mathrm{~mol} \mathrm{~L}^{-1} \mathrm{KBrO}_{3}$

\begin{tabular}{|c|c|c|c|c|c|}
\hline \multicolumn{3}{|c|}{$1 / 10 \mathrm{~mol} \mathrm{~L}^{-1} \mathrm{KI} \mathrm{O}_{3}$} & \multicolumn{3}{|c|}{$1 / 10 \mathrm{~mol} \mathrm{~L}^{-1} \mathrm{KBrO}_{3}$} \\
\hline $\begin{array}{l}\text { Wt. of DBTC taken } \\
\text { (mg) }\end{array}$ & $\begin{array}{l}\text { Wt. of DBTC found } \\
\qquad(\mathrm{mg})\end{array}$ & $\begin{array}{l}\text { Percentage of arsenic } \\
\text { found }\end{array}$ & $\begin{array}{l}\text { Wt. of DBTC taken } \\
(\mathrm{mg})\end{array}$ & $\begin{array}{l}\text { Wt. of DBTC found } \\
\text { (mg) }\end{array}$ & $\begin{array}{l}\text { Percentage of arsenic } \\
\text { found }\end{array}$ \\
\hline 14.10 & 14.02 & 15.08 & 11.02 & 10.98 & 15.11 \\
\hline 12.88 & 12.80 & 15.07 & 13.10 & 13.00 & 15.05 \\
\hline 11.90 & 12.02 & 15.32 & 10.98 & 11.16 & 15.42 \\
\hline 11.66 & 11.72 & 15.25 & 9.90 & 10.02 & 15.35 \\
\hline 13.90 & 13.82 & 15.08 & 13.32 & 13.36 & 15.22 \\
\hline 12.04 & 11.98 & 15.09 & 12.86 & 13.00 & 15.34 \\
\hline 13.04 & 13.10 & 15.24 & 14.04 & 13.98 & 15.10 \\
\hline 10.82 & 10.80 & 15.14 & 10.88 & 10.84 & 15.11 \\
\hline 9.90 & 10.00 & 15.32 & 11.36 & 11.40 & 15.22 \\
\hline \multirow[t]{2}{*}{11.76} & 11.86 & 15.17 & 12.06 & 11.98 & 15.07 \\
\hline & & $\begin{array}{l}\text { Mean value } \\
=151.76 / 10 \\
=15.18\end{array}$ & & & $\begin{array}{l}\text { Mean value } \\
=151.99 / 10 \\
=15.20\end{array}$ \\
\hline \multicolumn{3}{|c|}{ Mean percentage of arsenic $=15.18$} & \multicolumn{3}{|c|}{ Mean percentage of arsenic $=15.20$} \\
\hline \multicolumn{3}{|c|}{ Required value $=15.17$} & \multicolumn{3}{|c|}{ Required value $=15.17$} \\
\hline \multicolumn{3}{|c|}{ Standard deviation $=0.10$} & \multicolumn{3}{|c|}{ Standard deviation $=0.14$} \\
\hline \multicolumn{3}{|c|}{$\begin{array}{l}\text { Results up to } 99 \% \text { probability } \\
\text { truth }=15.18 \pm 0.10\end{array}$} & \multicolumn{3}{|c|}{$\begin{array}{l}\text { Results up to } 99 \% \text { probability } \\
\text { truth }=15.20 \pm 0.14\end{array}$} \\
\hline
\end{tabular}

Table 5.Visual volumetric titration of bis(dibromobutylene) bis(diphenyl arsine) dimercury(II) (BBDM) with $1 / 10 \mathrm{~mol} \mathrm{~L}^{-1} \mathrm{KIO}_{3}$ and $1 / 10$ mol L-1 $\mathrm{KBrO}_{3}$

\begin{tabular}{|c|c|c|c|c|c|}
\hline \multicolumn{3}{|c|}{$1 / 10 \mathrm{~mol} \mathrm{~L}^{-1} \mathrm{KIO}_{3}$} & \multicolumn{3}{|c|}{$1 / 10 \mathrm{~mol} \mathrm{~L}^{-1} \mathrm{KBrO}_{3}$} \\
\hline $\begin{array}{l}\text { Wt. of BBDM taken } \\
(\mathrm{mg})\end{array}$ & $\begin{array}{l}\text { Wt. of BBDM found } \\
(\mathrm{mg})\end{array}$ & $\begin{array}{l}\text { Percentage of arsenic } \\
\text { found }\end{array}$ & $\begin{array}{l}\text { Wt. of BBDM taken } \\
(\mathrm{mg})\end{array}$ & $\begin{array}{l}\text { Wt. of BBDM found } \\
(\mathrm{mg})\end{array}$ & $\begin{array}{l}\text { Percentage of arsenic } \\
\text { found }\end{array}$ \\
\hline 13.98 & 14.02 & 12.17 & 10.82 & 10.76 & 12.07 \\
\hline 12.02 & 11.98 & 12.10 & 11.88 & 12.02 & 12.28 \\
\hline 12.66 & 12.70 & 12.18 & 13.14 & 12.98 & 11.99 \\
\hline 11.36 & 11.42 & 12.20 & 12.12 & 12.20 & 12.22 \\
\hline 9.90 & 10.00 & 12.26 & 10.48 & 10.54 & 12.21 \\
\hline 14.76 & 14.82 & 12.19 & 10.06 & 10.20 & 12.30 \\
\hline 12.88 & 12.98 & 12.23 & 11.82 & 11.78 & 12.10 \\
\hline 11.06 & 11.02 & 12.09 & 9.96 & 10.02 & 12.21 \\
\hline 10.86 & 10.92 & 12.21 & 12.38 & 12.44 & 12.20 \\
\hline \multirow[t]{2}{*}{13.70} & 13.66 & 12.10 & 10.76 & 10.68 & 12.05 \\
\hline & & $\begin{array}{c}\text { Mean value } \\
=121.73 / 10 \\
=12.17\end{array}$ & & & $\begin{array}{l}\text { Mean value } \\
=122.63 / 10 \\
=12.26\end{array}$ \\
\hline \multicolumn{3}{|c|}{ Mean percentage of arsenic $=12.17$} & \multicolumn{3}{|c|}{ Mean percentage of arsenic $=12.26$} \\
\hline \multicolumn{3}{|c|}{ Required value $=12.14$} & \multicolumn{3}{|c|}{ Required value $=12.14$} \\
\hline \multicolumn{3}{|c|}{ Standard deviation $=0.07$} & \multicolumn{3}{|c|}{ Standard deviation $=0.11$} \\
\hline \multicolumn{3}{|c|}{$\begin{array}{l}\text { Results up to } 99 \% \text { probability } \\
\text { truth }=12.17 \pm 0.07\end{array}$} & \multicolumn{3}{|c|}{$\begin{array}{l}\text { Results up to } 99 \% \text { probability } \\
\text { truth }=12.26 \pm 0.11\end{array}$} \\
\hline
\end{tabular}

It has been observed that the mean percentage of arsenic recorded were 15.18 and $15.20 \%$ against the required values of 15.17 and $15.17 \%$ and standard deviation of 0.1 and 0.14 for potassium iodate and potassium bromate, respectively (Table 4). Table 5 shows the estimation of arsenic in mercury (II) complexes using potassium iodate and potassium bromate oxidants. The nascent oxygen liberated in the following reaction, oxidised arsenic(III) in organic arsenic compounds to arsenic(IV) compounds. 


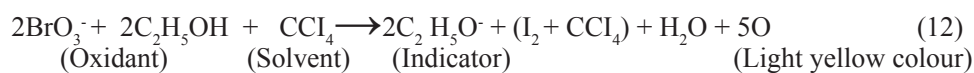

$\left(\mathrm{C}_{6} \mathrm{H}_{5) 3} \mathrm{As}+\mathrm{O} \longrightarrow\left(\mathrm{C}_{6} \mathrm{H}_{5}\right)_{3} \mathrm{As}=\mathrm{O}\right.$

It was recorded that the estimation was accurate in both cases with standard deviations of 0.07 and $0.11 \%$ respectively.

$\mathrm{BrO}_{3}^{-}+5 \mathrm{Br}+6 \mathrm{H}^{+} \longrightarrow 3 \mathrm{Br}_{2}+3 \mathrm{H}_{2} \mathrm{O}$

$\mathrm{Br}_{2}+\mathrm{CCI}_{4} \longrightarrow\left(\mathrm{Br}_{2}+\mathrm{CCI}_{4}\right)$

(light yellow colour)

Conductometric titrations

The conductometric titrations of triphenyl arsine with potassium iodate and potassium bromate oxidants were shown in Table 6 and Fig.1 and 2. The conductivity was due to the presence of ions, as shown in equations (3), (5), (6) and (7).

Table 6. Potentiometric titration with $1 / 10 \mathrm{~mol} \mathrm{~L}^{-1} \mathrm{KIO}_{3}$ and $1 / 10 \mathrm{~mol} \mathrm{~L}^{-1} \mathrm{KBrO}_{3}$

\begin{tabular}{|c|c|c|c|}
\hline \multicolumn{2}{|c|}{$1 / 10 \mathrm{~mol} \mathrm{~L}^{-1} \mathrm{KIO}_{3}$ solution Vs Solution of triphenyl arsine } & \multicolumn{2}{|c|}{$1 / 10 \mathrm{~mol} \mathrm{~L}^{-1} \mathrm{KBrO}_{3}$ solution Vs Solution of triphenyl arsin } \\
\hline $\begin{array}{c}\text { Volume of } \\
\text { 1/10 } \mathrm{mol} \mathrm{L}^{-1} \mathrm{KI} \mathrm{O}_{3} \text { solution } \\
\text { added }(\mathrm{mL})\end{array}$ & $\begin{array}{l}\text { Potential value } \\
\qquad(\mathrm{mV})\end{array}$ & $\begin{array}{c}\text { Volume of } \\
1 / 10 \mathrm{~mol} \mathrm{~L}^{-1} \mathrm{KBrO}_{3}(\mathrm{~mL})\end{array}$ & $\begin{array}{l}\text { Potential value } \\
\quad(\mathrm{mV})\end{array}$ \\
\hline 0.2 & 190. & 0.4 & 182 \\
\hline 0.4 & 160 & 0.8 & 163 \\
\hline 0.6 & 140 & 1.0 & 134 \\
\hline 0.8 & 130 & 1.4 & 120 \\
\hline 1.0 & 110 & 1.8 & 105 \\
\hline 1.2 & 100 & 2.2 & 100 \\
\hline 1.4 & 92 & 2.6 & 94 \\
\hline 1.6 & 90 & 3.0 & 88 \\
\hline 1.8 & 88 & 3.4 & 84 \\
\hline 2.0 & 84 & 3.8 & 80 \\
\hline 2.10 & 86 & 4.0 & 86 \\
\hline 2.16 & 90 & 4.10 & 88 \\
\hline 2.20 & 110 & 4.20 & 290 \\
\hline 2.22 & 114 & 4.22 & 296 \\
\hline 2.24 & 252 & 4.24 & 300 \\
\hline 2.26 & 270 & 4.26 & 312 \\
\hline 2.28 & 272 & 4.30 & 314 \\
\hline 2.30 & 274 & 4.32 & 314 \\
\hline 2.32 & 280 & & \\
\hline 2.34 & 280 & & \\
\hline \multicolumn{2}{|c|}{ wt. of triphenyl arsine taken $=12.08 \mathrm{mg}$} & \multicolumn{2}{|c|}{ wt. of triphenyl arsine taken $=11.80 \mathrm{mg}$} \\
\hline \multicolumn{2}{|c|}{ wt. of triphenyl arsine found $=11.98 \mathrm{mg}$} & \multicolumn{2}{|c|}{ wt. of triphenyl arsine found $=11.68 \mathrm{mg}$} \\
\hline \multicolumn{2}{|c|}{$\%$ age of arsenic required $=11.83 \%$} & \multicolumn{2}{|c|}{$\%$ age of arsenic required $=11.83 \%$} \\
\hline \multicolumn{2}{|c|}{$\%$ age of arsenic found $=11.73 \%$} & \multicolumn{2}{|c|}{$\%$ age of arsenic found $=11.71 \%$} \\
\hline
\end{tabular}

The results of conductometric titration were sharp and reproducible. The percentage of arsenic recovered was $11.89 \%$ for $1 / 10 \mathrm{~mol} \mathrm{~L}^{-1} \mathrm{KIO}_{3}$ and $11.70 \%$ for $1 / 10 \mathrm{~mol} \mathrm{~L}^{-1} \mathrm{KBrO}_{3}$

Potentiometric titration

The potentiometric titration of triphenyl arsine with potassium iodate and potassium bromate oxidants is shown in Table 7 and Fig. 3 and 4. 
J. Chil. Chem. Soc., 61, No 2 (2016)

Table 7. Conductometric titration with $1 / 10 \mathrm{~mol} \mathrm{~L}^{-1} \mathrm{KI} \mathrm{O}_{3}$ and $1 / 10 \mathrm{~mol} \mathrm{~L}^{-1} \mathrm{KBrO}_{3}$

\begin{tabular}{|c|c|c|c|}
\hline \multicolumn{2}{|c|}{$1 / 10 \mathrm{~mol} \mathrm{~L}^{-1} \mathrm{KIO}_{3} \mathrm{Vs}$ Solution of triphenyl arsine } & \multicolumn{2}{|c|}{$1 / 10 \mathrm{~mol} \mathrm{~L}^{-1} \mathrm{KBrO}_{3}$ solution Vs Solution of triphenyl arsine } \\
\hline $\begin{array}{c}\text { Volume of } \\
1 / 10 \mathrm{~mol} \mathrm{~L}^{-1} \mathrm{KIO}_{3} \text { solution added }(\mathrm{mL})\end{array}$ & $\begin{array}{l}\text { Conductometric value } \\
\qquad\left(\mathrm{S} \mathrm{cm}^{-}\right)\end{array}$ & $\begin{array}{c}\text { Volume of } \\
1 / 10 \mathrm{~mol} \mathrm{~L}^{-1} \mathrm{KBrO}_{3} \text { added }(\mathrm{mL}) \\
\end{array}$ & $\begin{array}{l}\text { Conductometric value } \\
\left(\mathrm{S} \mathrm{cm}^{-}\right)\end{array}$ \\
\hline 0.00 & $32.2 \times 10^{-3}$ & 0.00 & $8.2 \times 10^{-3}$ \\
\hline 0.20 & $30.0 \times 10^{-3}$ & 0.20 & $7.8 \times 10^{-3}$ \\
\hline 0.40 & $28.4 \times 10^{-3}$ & 0.4 & $7.2 \times 10^{-3}$ \\
\hline 0.60 & $26.8 \times 10^{-3}$ & 0.6 & $6.6 \times 10^{-3}$ \\
\hline 0.80 & $26.2 \times 10^{-3}$ & 1.0 & $6.4 \times 10^{-3}$ \\
\hline 1.00 & $25.4 \times 10^{-3}$ & 1.4 & $5.8 \times 10^{-3}$ \\
\hline 1.20 & $25.0 \times 10^{-3}$ & 1.8 & $5.4 \times 10^{-3}$ \\
\hline 1.40 & $22.6 \times 10^{-3}$ & 2.0 & $5.1 \times 10^{-3}$ \\
\hline 1.60 & $21.8 \times 10^{-3}$ & 2.4 & $4.9 \times 10^{-3}$ \\
\hline 1.80 & $20.1 \times 10^{-3}$ & 2.6 & $4.4 \times 10^{-3}$ \\
\hline 2.20 & $16.7 \times 10^{-3}$ & 3.0 & $4.0 \times 10^{-3}$ \\
\hline 2.10 & $16.0 \times 10^{-3}$ & 3.4 & $4.2 \times 10^{-3}$ \\
\hline 2.12 & $14.4 \times 10^{-3}$ & 3.6 & $4.8 \times 10^{-3}$ \\
\hline 2.14 & $13.6 \times 10^{-3}$ & 3.7 & $5.0 \times 10^{-3}$ \\
\hline 2.16 & $12.6 \times 10^{-3}$ & 3.8 & $6.4 \times 10^{-3}$ \\
\hline 2.17 & $12.6 \times 10^{-3}$ & 3.9 & $6.4 \times 10^{-3}$ \\
\hline 2.18 & $12.6 \times 10^{-3}$ & 4.1 & $6.4 \times 10^{-3}$ \\
\hline 2.20 & $12.6 \times 10^{-3}$ & 4.2 & $6.4 \times 10^{-3}$ \\
\hline 2.22 & $12.6 \times 10^{-3}$ & & \\
\hline \multicolumn{2}{|c|}{ wt. of triphenyl arsine taken $=11.54 \mathrm{mg}$. } & \multicolumn{2}{|c|}{ wt. of triphenyl arsine taken $=10.72 \mathrm{mg}$} \\
\hline \multicolumn{2}{|c|}{ wt. of triphenyl arsine found $=11.60 \mathrm{mg}$} & \multicolumn{2}{|c|}{ wt. of triphenyl arsine found $=10.60 \mathrm{mg}$} \\
\hline \multicolumn{2}{|c|}{$\%$ age of arsenic required $=11.83 \%$} & \multicolumn{2}{|c|}{$\%$ age of arsenic required $=11.83 \%$} \\
\hline \multicolumn{2}{|c|}{$\%$ age of arsenic found $=11.89 \%$} & \multicolumn{2}{|c|}{$\%$ age of arsenic found $=11.70 \%$} \\
\hline
\end{tabular}

The potential (E) recorded is due to the following Nernst equation.

$$
E=E^{0}+\frac{0.0591}{\mathbf{n}} \log \frac{\{\mathrm{Ox}\}}{\{\text { Red }\}}
$$

The organic compound containing arsenic (III) was determined potentiometrically. The potassium iodate and potassium bromate were used as titrants. The end points were sharp and reproducible. The percentage of arsenic for $1 / 10 \mathrm{~mol} \mathrm{~L}^{-1} \mathrm{KIO}_{3}$ and $1 / 10 \mathrm{~mol} \mathrm{~L}^{-1} \mathrm{KBrO}_{3}$ were found to be $11.73 \%$ and $11.71 \%$, respectively. The results obtained were within standard deviation error.

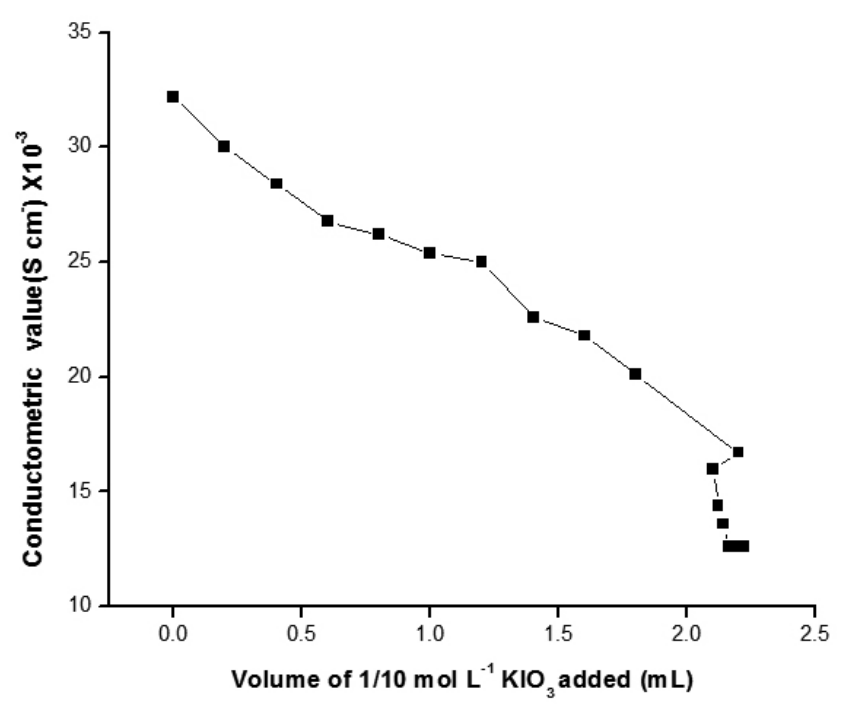
$\mathrm{KIO}_{3}$

Figure 1. Conductometric titration of triphenyl arsine with $1 / 10 \mathrm{~mol} \mathrm{~L}^{-1}$ 


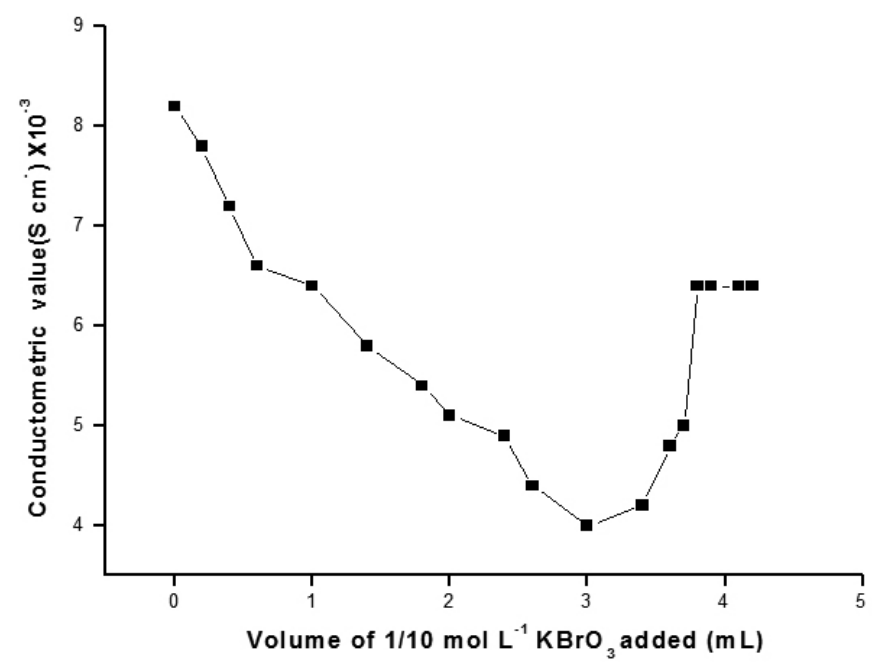

Figure 2.Conductometric titration of triphenylarsine with $1 / 10 \mathrm{~mol}$ $\mathrm{L}^{-1} \mathrm{KBrO}_{3}$

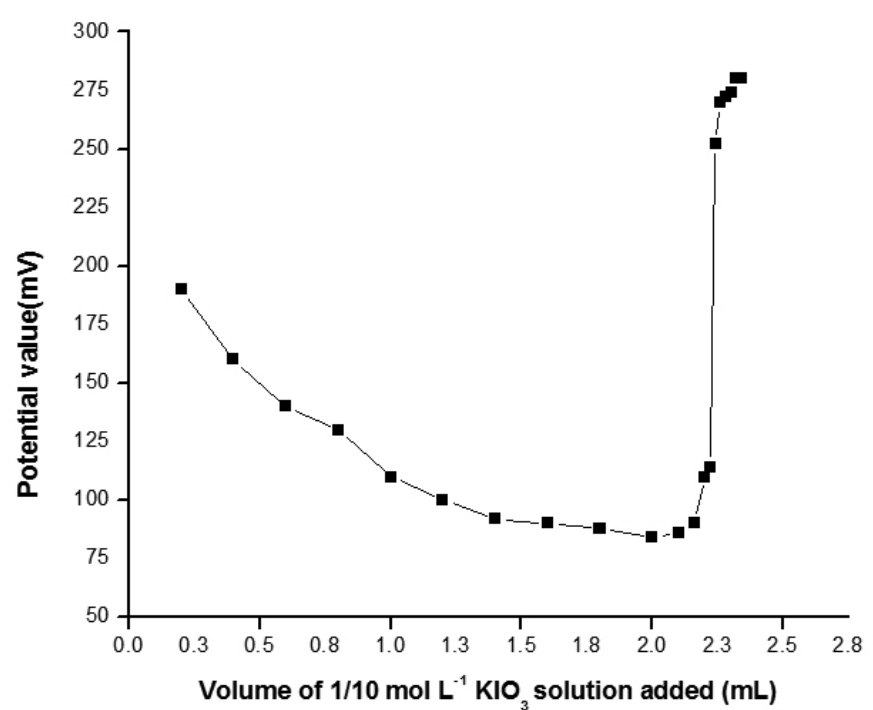

Figure 3. Potentiometric titration of triphenylarsine with $1 / 10 \mathrm{~mol} \mathrm{~L}^{-1} \mathrm{KIO}_{3}$

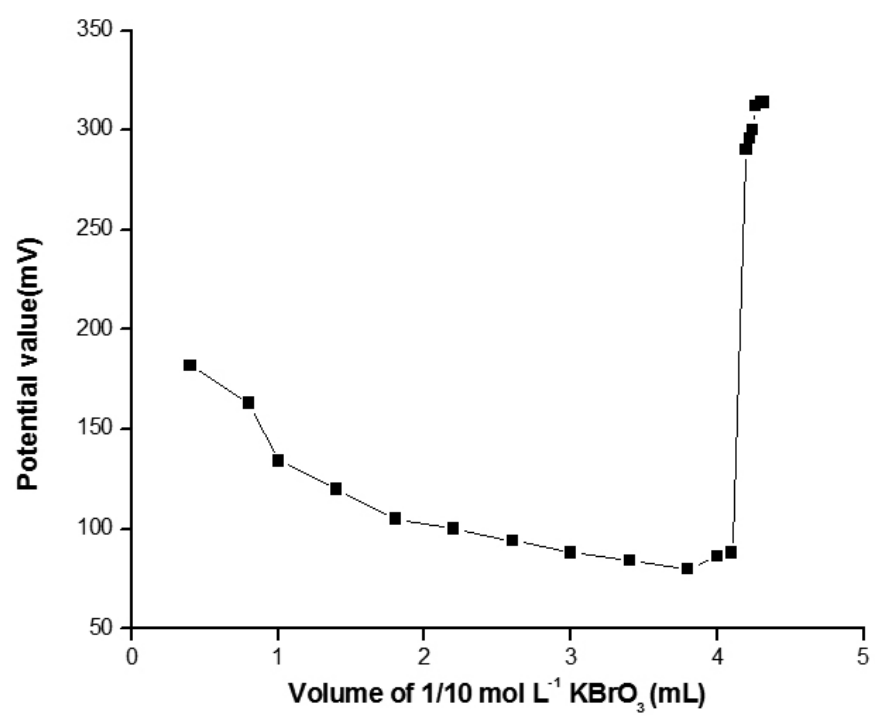
$\mathrm{KBrO}_{3}$

\section{CONCLUSION}

In the present study, the solution of small quantity $(10-20 \mathrm{mg})$ of the organic compound containing arsenic(III) and its complexes containing tin(IV) and $\mathrm{Hg}(\mathrm{II})$ in ethanol, water and hydrochloric acid were determined visually, conductometerically and potentiometrically using standard potassium iodate and potassium bromate as oxidants. The results obtained were within standard deviation of $99 \%$ probability truth. These results are comparable to already known methods in the literature.

\section{ACKNOWLEDGEMENTS}

The authors acknowledge the School of Chemistry, Shoolini University, Solan for providing all necessary research facilities. One of the authors $\mathrm{Mu}$. Naushad) acknowledges the King Saud University, Deanship of Scientific Research college of Science Research centre for the support.

\section{REFERENCES}

1. Kumar, A.; Sharma, G.; Naushad, M.; Thakur, S; Chem. Eng. J. 2015, 280, 175 .

2. Pathania, D.; Sharma, G.; Kumar, A.; Naushad, M.; Kalia, S.; Sharma, A.; ALOthman, Z A .; Toxicol. \& Enviro. Chem. 2015, 97, 526.

3. Naushad, M.; ALOthman, Z. A.; Awual, M.R.; Alam, M.M.; Ionics 2015, 21, 2237.

4. Sharma, G.; Naushad, M.; Kumar, A.; Devi, S.; Khan, M. R.; Iranian Polymer Journal 2015, 24, 1003.

5. Pathania, D.; Gupta, D.; Kothiyal, N.C.; Sharma, G.; Eldesoky, G.E.; Naushad, M.; Int. J. Bio. Macromol. 2016, 84, 340.

6. Naushad, M.; Khan, M.R.; ALOthman, Z.A.; AlSohaimi, I.; RodriguezReinoso, F.; Turki, T.M.; Ali, R.; Env. Sci. \& Poll. Res. 2015, 22, 15853.

7. Sharma, G.; Pathania, D.; Naushad, M.; Ionics, 2015, 21, 1045.

8. Gupta, V.K.; Sharma, G.; Pathania, D.; Kothiyal N.C.; J. Ind. Eng. Chem. 2015, 21, 957

9. Katwal, R; Kaur, H; Sharma, G; Naushad, M; Pathania D.; J. Ind. Eng. Chem. 2015, 31, 173.

10. Sharma, G.; Kumar, A.; Naushad, M.; Pathania D.; Sillanpaa, Mika.; J. Ind. Eng. Chem. 2016, 33, 201.

11. Pathania D.; Katwal, R; Sharma, G.; Naushad, M.; Khan, M. R.; AlMuhtaseb A. H.; Inter. J. Bio. Macromolecul. 2016, 87, 366.

12. Kumar, A.; Guo, C.; Sharma, G.; Pathania, D.; Naushad, M.; Kalia, S.; Dhiman P.; RSC Advances 2016, 6, 13251.

13. Naushad, M.; ALOthman, Z A .; Sharma, G.; Inamuddin.; Ionics 2015, 21,1453

14. Pathania, D.; Sharma, G.; Naushad, M.; Priya, V.; Desal. Water Treat. 2016, 57, 468.

15. Sharma, G.; Pathania, D.; Naushad, M.; J. Ind. Eng. Chem. 2014, 20, 4482.

16. Pifer, C.W.; Wollish, E.G.; Anal Chem. Anal. Chem.1952, 24, 519.

17. Belcher, R.; Fleet, B.; J. Chem. Soc.1965,15,1740.

18. Blumrich, K.; Bandol, G.; Angew. Chem.1941, 54, 374.

19. Moore, R.T.; Cutchan, P. M.; Young, D.A. ;Anal. Chem.1951, 23,1630.

20. Terry, D.E.; Eilar, K.R. ; Moe, O.A.; Anal. Chem.1952, 24, 313

21. Lippincott, W.T.; Timnick, A.; Anal. Chem.1956, 28, 1690.

22. Sensi, P.; Gallo, G.G.; Ann. Chim. (Rome) 1953, 43,453.

23. Wimer, D.C.; Anal. Chem.1952, 34, 873

24. Ludmila, S.; Zyka, T. ;J. Electro. Anal.Chem.1963, 5, 57.

25. Mindalev, Z.; Anal. Chem.1928, 75, 392.

26. Cassidy, N.G.; Analyst.1956, 81, 169.

27. Konovalov, A.; Ind. Chim. Belge.,1961, 26, 1257.

28. Brunisholz, G.; Michod, J. ;Helv. Chim.,Acta.,1954, 37, 598.

29. Brunisholz, G.; Helv. Chin, Acta.,1954, 37,1546.

30. Bray, W.C.; Z. Physik. Chem.,1905, 54, 576.

31. Jacksom, D.T.; Parsons, J.L.; Ind. Eng. Chem., Anal. Ed.1937, 9, 14.

32. Gysel., H.; Helv. Chim.Acta., 1941, 24, 128.

33. Ligget, L.M.; Anal. Chem, 1954, 26, 748.

34. Belcher, R.; Thompson, J.H.; West, T.S.; Anal. Chim.Acta.1958,35 309.

35. Ashworth, M. R. F. ;Fehringer, R. ; Anal. Chim.Acta.1966,35,111.

36. Ingram, G.; Chapman and Hall, London, 1964,pp 105.

37. Garelli, F.; Chimie and Industrie special No. 262 (June, 1933). CA: 27, 5680.

38. Poggi, R.; Polverini, A.; Atti. Accad.Lincei.1926, 6, 315.

39. Gupta, H. N. D. ;J. Indian Chem. Soc.1932, 9, 203. 
40. Fargher, R.G.; J Chem. Soc.,1919, 115, 982.

41. Bystrov, S.P. ;Sheverdyaeva, V.M. ; Aptechn. Delo.1964, 13, 47.

42. Woy, F. ;Chem. Ztg.,1897, 21, 442.
43. Sandhu, S.S. ;Anal. Chim.Acta.1971, 56, 154.

44. Liming, Z.; Institute of Chem. Defence, Beijing, 2008. 